\title{
ANTIDIABETIC AND ANTIOXIDANT ACTIVITIES OF ETHANOLIC EXTRACT OF PIPER BETLE L. LEAVES IN CATFISH, CLARIAS GARIEPINUS
}

\author{
PARTHASARATHI PERUMAL, KAVITHA SARAVANABHAVAN*
}

*Assistant Professor of Biotechnology, Department of Biotechnology, Prince Shri Venkateshwara Arts and Science College, Gowrivakkam, Chennai - 600073, Tamil Nadu, India. Email: saranva.k@gmail.com

Received: 05 September 2017, Revised and Accepted: 01 December 2017

\section{ABSTRACT}

Objective: The present study was undertaken to assess the $\alpha$-amylase inhibitory activity and antidiabetic experimental catfish model and antioxidant properties of Piper betle L. ethanolic extract.

Methods: The phytochemical analysis of Piper betle L. ethanolic extract was performed. The Piper betle L. ethanolic extract was tested for their inhibitory effect on the $\alpha$-amylase assay, which compared to the control, acarbose. The absorbance was read at $540 \mathrm{~nm}$ using a spectrophotometer, and $\mathrm{IC}_{50}$ values were calculated. In this present investigation, diabetes mellitus was induced in catfish, Clarias gariepinus by epaxial musculature injection to glucose and standard drug, Metformin hydrochloride. After 24-h incubation, the treated fishes were dissected, and the blood, liver, tissue samples, and epaxial musculature regions were collected. In addition, the antioxidant properties of PBE were determined by 2,2-diphenyl-l-picrylhydrazyl radical scavenging and 2,2'-azino-bis(3-ethylbenzothiazoline-6-sulfonic acid) radical scavenging assays.

Results: The phytochemical screening of PBE revealed the presence of alkaloid, flavonoids, tannins, phenol, glycosides, sterols, saponins, and quinines. Also, the values of $(\mu \mathrm{g} / \mathrm{ml}) 3.038$ and $7.672 \alpha$-amylase enzyme inhibition were excellent activity when compared to the acarbose. And, elevated the glucose level $(\mathrm{mg} / \mathrm{dl})$ was estimated in blood $1.9 \pm 0.35$, liver $0.5 \pm 0.25$, tissue $0.2 \pm 0.25$, and epaxial musculature $0.8 \pm 0.2$ after 24 -h incubation. The antioxidant effect of maximum activity was found in PBE IC ${ }_{50}$ values $(\mu \mathrm{g} / \mathrm{ml})$ of DPPH and ABTS were 9.362 and 6.606, respectively.

Conclusions: In this studies might be responsible for the $P$. betle L. was used as the new source of antidiabetic and antioxidant agents.

Keywords: Piper betle L., Clarias gariepinus, Acarbose, Antioxidant activity.

(c) 2018 The Authors. Published by Innovare Academic Sciences Pvt Ltd. This is an open access article under the CC BY license (http://creativecommons. org/licenses/by/4. 0/) DOI: http://dx.doi.org/10.22159/ajpcr.2018.v11i3.22393

\section{INTRODUCTION}

Diabetes mellitus is a chronic metabolic disorder, is one of the most important problems in public health nowadays [1,2]. It is characterized by high levels of glucose in the blood due to the impaired secretion of insulin insensitivity [3]. A globally around $4 \%$ population was affecting and could be predictable to increase by $5.4 \%$ in 2025 . Worldwide the number of adults suffering from diabetes will increase from 194 million in 2003 to nearly 380 million in 2030 [4]. Currently, the available therapy for diabetes includes insulin and various oral antidiabetic agents such as sulfonylureas, thiazolidinediones, and $\alpha$-glucosidase inhibitors etc. Hence antidiabetic drug discovery has shifted to focus on natural product and plant sources having minimal side effects. Plants have played a major role in the new therapeutic agents for the antidiabetic drug [5]. Experimental animal models are one of the best strategies for the understanding of the pathophysiology of any disease to design and develop the drugs for its treatment [6]. Numerous animal models have been developed over the past few decades for studying diabetes mellitus and testing antidiabetic agents that include chemical, surgical, and genetic manipulations $[7,8]$. One of the most potent methods to induce experimental diabetes mellitus is chemical induction by alloxan and metformin hydrochloride. It is a well-known diabetogenic agent that is used to induce Type I and Type II diabetes in experimental animals [9].

Piper betle L. Piperaceae, a dioecious, annual creeper, climbing by many small adventitious rootless, grows to a height of about one $\mathrm{m}$, generally grown in hotter and damper parts of the country. It is extensively found in damp forests and is propagated in India, Southeast Asia, Vietnam, and China [10]. P. betle L. contains a wide variety of biologically active compounds whose concentration depends on the variety of the plant, season, and climate. The pharmacological profile has shown antiplatelet, anti-inflammatory effects as well as immunomodulatory, gastroprotective, and antidiabetic activity [11]. The leaves are given for gastric and lung disorders in children and applied to purulent ulcers. They have a high content of potassium nitrate $(0.26-0.42 \%)$. The sugars identified in betel leaves include glucose, fructose, maltose, and sucrose. Extracts of $P$. betle $\mathrm{L}$. are used for the treatment of various ailments since ages due to its essential properties such as antibacterial, antioxidant, anticancer, and antiallergic [12,13]. The antidiabetic activity of the aqueous and alcoholic extract of Epipremnum aureum was determined by alloxan-induced diabetic rats. Flavonoids might be producing the hypoglycemic effect by a mechanism independent of insulin secretion, e.g., by the inhibition of endogenous glucose production or by the inhibition of intestinal glucose absorption [14]. Hence, this present study was taken up to investigate the antidiabetic and antioxidant activities of the $P$. betle $\mathrm{L}$. in induced diabetic fish. This is the first report to antidiabetic activity of $P$. betle $\mathrm{L}$. extract in induced fish model.

\section{MATERIALS AND METHODS}

\section{Collection}

P. betle L. leaves were collected from Tirunelveli District, Tamil Nadu. The samples were washed thoroughly with tap water and then distilled water to remove the debris and then shadow dried for 2 weeks. The samples were preserved in $4 \%$ formalin and all the sample specimens were kept in our research laboratory for further study. The samples were observed by macro- and microscopic analyses [15]. Finally, the samples were powdered using an electric blender. The adult catfish, Clarias gariepinus (body weight 180-190 g and length $15-20 \mathrm{~cm}$ ), was procured from the commercial source. Animals were maintained under the controlled laboratory conditions of light and temperature and were fed with laboratory food (CIBA, Chennai) as 
followed by [16]. The catfish, C. gariepinus, was identified by macroand microscopic analyses $[17,18]$. All the reagents and chemicals were of analytical grade and purchased from HiMedia, India, and local suppliers Chennai.

\section{Preparation of $P$. betle ethanolic extract}

$10 \mathrm{~g}$ of dried powered material was extracted with $100 \mathrm{ml}$ ethanol using Soxhlet apparatus. The ethanol extract was concentrated by rotary evaporator. Finally, the collected extract was stored at $4^{\circ} \mathrm{C}$.

\section{Phytochemical screening}

The samples $P$. betle $\mathrm{L}$. ethanol extracted (PBE) were subjected to preliminary phytochemical screening as described by [19].

\section{In vitro antidiabetic activity of $\alpha$-amylase assay}

The $\alpha$-amylase activity of PBE was measured according to the modified method of [20]. The $\alpha$-amylase was dissolved in phosphate-buffer saline $(0.02 \mathrm{~mol} / \mathrm{l}, \mathrm{pH} 6.8)$ at a concentration of $0.1 \mathrm{mg} / \mathrm{ml}$. The various concentrations of sample solutions $(3.125,6.25,12.5,25,50$, and $100 \mu \mathrm{g} / \mathrm{ml})$ were mixed with the $\alpha$-amylase solution $(0.25 \mathrm{ml})$ and incubated at $37^{\circ} \mathrm{C}$ for $5 \mathrm{~min}$. Then, the reaction was initiated by adding $0.5 \mathrm{ml} 1.0 \%(\mathrm{w} / \mathrm{v}$ ) starch substrate solution to the incubation medium. After incubation at $37^{\circ} \mathrm{C}$ for $3 \mathrm{~min}$, the reaction was stopped by adding $0.5 \mathrm{ml}$ reagent (1\% dinitrosalicylic acid, $0.05 \% \mathrm{Na}_{2} \mathrm{SO}$, and $1 \% \mathrm{NaOH}$ solution) to the reaction mixture and boiling at $100^{\circ} \mathrm{C}$ for $5 \mathrm{~min}$. After cooling to room temperature, the absorbance (Abs) at $540 \mathrm{~nm}$ was recorded by a spectrophotometer. The inhibition percentage was calculated by the following equation: Inhibition (\%)=[(Abs1 - Abs2)/ Abs 1$] \times 100$

Where, Abs1 is the sample and Abs2 is the control.

In vivo antidiabetic activity of glucose-induced fish (orthotoluidine method)

The in vivo study was performed in Clarias gariepinus (catfish) purchased from Kunnavakkam, Kanchipuram, Tamil Nadu, and slightly modified procedure by [21]. The fish sample was maintained under laboratory condition. The glucose, metformin hydrochloride, and ethanolic extract of $P$. betle L. were prepared and the concentration ranging from $200 \mathrm{mg} / \mathrm{ml}$.

\section{Preparation of test sample}

The blood samples were directly centrifuged at $3000 \mathrm{rpm}$ for $10 \mathrm{~min}$ and the serum was collected. The other tissue samples were separately grinded using normal saline. The suspension was centrifuged and the supernatants were separately collected. $100 \mu \mathrm{l}$ of blood serum and supernatant were taken in separate test tubes and was made up to 5 $\mathrm{ml}$ of distilled water. The four groups ( 3 fish each) were taken. Group 1: Control - the fishes were dissected, and the blood, liver, tissue, and epaxial musculature samples were collected. Group 2: Fish injected with glucose (diabetic control). $200 \mathrm{mg}$ of glucose was dissolved in sterile distilled water and injected into the epaxial musculature. After $3 \mathrm{~h}$, the fishes were dissected and the blood, liver, tissue, and epaxial musculature were collected. Group 3: Fish injected with glucose and metformin hydrochloride. $200 \mathrm{mg}$ of glucose was dissolved in sterile water and injected into the epaxial musculature region. After 3-h incubation, $1 \mathrm{ml}$ of standard drug (metformin hydrochloride) was injected. The injected fishes were observed for $24 \mathrm{~h}$ and the treated fishes were dissected and the blood, liver, tissue, and epaxial musculature samples were collected. Group 4: Fish injected with glucose and plant extract. $200 \mathrm{mg}$ of glucose was dissolved in sterile water and injected into the epaxial musculature. After 3-h incubation, $1 \mathrm{ml}$ of extract was injected. The injected fishes were observed for $24 \mathrm{~h}$ and the treated fishes were dissected and the blood, liver, tissue, and epaxial musculature were collected. The distilled water was added to make up all the test tubes with $5 \mathrm{ml} .5 \mathrm{ml}$ of ortho-toluidine reagent was added to all the test tubes, shaken well, and heated in a boiling water bath for $20 \mathrm{~min}$, till a bluish green color develops. The tubes were cooled and Abs was read at $660 \mathrm{~nm}$ using the spectrophotometer.

\section{Antioxidant activity}

DPPH (2, 2-diphenyl-1-picrylhydrazyl) radical scavenging assay

DPPH (2, 2-diphenyl-1-picrylhydrazyl) radical scavenging assay of PBE was modified method described by [22]. In brief, $0.135 \mathrm{mM} \mathrm{DPPH}$ was prepared in methanol. Different concentration of extract $(1,5,10$, 20,50 , and $100 \mu \mathrm{g} / \mathrm{ml}$ ) was mixed with $1.9 \mathrm{ml}$ of DPPH solution and was kept at room temperature for $30 \mathrm{~min}$. The Abs of the mixture was measured at $517 \mathrm{~nm}$. The ability of plant extract to scavenge DPPH radical and control was calculated from the following formula:

$\%$ DPPH inhibition=[(OD of control - OD of test $) /($ OD of control $)] \times 100$.

ABTS (2, 2'-Azino-Bis (3-Ethylbenzothiazoline-6-Sulphonic acid) radical scavenging assay

ABTS (2, 2'-Azino-Bis (3-Ethylbenzothiazoline-6-Sulphonic acid) radical scavenging assay of PBE was performed according to the method of [23]. The ABTS (7 mM, $25 \mathrm{ml}$ in deionized water) stock solution was prepared with potassium persulfate (K2S208) $(140 \mathrm{mM}, 440 \mu \mathrm{l})$. The different concentrations of the extracts $(1,5,10,20,50$, and $100 \mu \mathrm{g} / \mathrm{ml})$ were mixed with the ABTS working solution $(1.9 \mathrm{ml})$ and the reaction mixture was allowed to stand at room temperature for $20 \mathrm{~min}$; then, the Abs was measured using an ultraviolet-visible spectrophotometer at $734 \mathrm{~nm}$. The radical scavenging activity was given as ABTS radical scavenging effect was calculated by the equation:

ABTS radical scavenging effect $(\%)=[(\mathrm{A} 0-\mathrm{A} 1) / \mathrm{A} 0] \times 100$

Where, $\mathrm{A} 0$ is the control; $\mathrm{A} 1$ is the test

\section{Statistical analysis}

The activity of PBE was measured by the inhibitory concentration ( IC $\left._{50}\right)$ values that were calculated using GraphPad Prism version 5.

\section{RESULTS}

\section{Phytochemical screening}

Alkaloid, flavonoid, tannin, phenol, glycoside, sterol, saponin, and quinone were found in ethanolic extract Table 1.

\section{In vitro antidiabetic activity of $\alpha$-amylase assay}

In the present study, PBE extract of in vitro antidiabetic activity was investigated for their potential to dose-depended increase in percentage inhibitory against $\alpha$-amylase assay. The five different concentrations were using, namely, 3.125, 6.25, 12.5, 25, 50, and $100 \mu \mathrm{g} / \mathrm{ml}$. Among the extract showed highest antidiabetic activity when compared to the control acarbose. The extract of $P$. betle $\mathrm{L}$. leaf showed strongly effect on the $\alpha$-amylase assay along with the PBE extract of inhibition values of $\mathrm{IC}_{50}(\mu \mathrm{g} / \mathrm{ml})$, viz;, 3.038 and 7.672. The results were given in Table 2.

\section{In vivo antidiabetic activity of glucose-induced fish}

The antidiabetic activity was observed in normal fish; glucose levels were estimated in blood, liver, tissues, and epaxial musculature samples range at $(\mathrm{mg} / \mathrm{dl}) 1.3 \pm 0.15,0.5 \pm 0.1,0.02 \pm 0.02$ and $0.01 \pm 0.00$, respectively. After $3 \mathrm{~h}$, glucose-induced fish hyperglycemic level was observed in $(\mathrm{mg} / \mathrm{dl}) 3.7 \pm 0.2,0.5 \pm 0.20,0.2 \pm 0.20$, and $3.6 \pm 0.2$, respectively. And the $P$. betle L. ethanolic extract were treated with glucose-induced fish range from $(\mathrm{mg} / \mathrm{dl}) 1.9 \pm 0.35,0.5 \pm 0.25,0.2 \pm 0.25$, and $0.8 \pm 0.2$, when the results were compared with standard drug, which values show in $(\mathrm{mg} / \mathrm{dl}) 1.0 \pm 0.40,0.2 \pm 0.1,0.2 \pm 0.26$, and $0.2 \pm 0.1$, respectively. The results were given in Table 3 injections of glucoseinduced fish level range were observed at after $24 \mathrm{~h}$.

\section{In vitro antioxidant activity} DPPH radical scavenging assay

The mean $\mathrm{IC}_{50}$ value $(\mu \mathrm{g} / \mathrm{ml})$ for DPPH radical of ascorbic acid was found to be 3.128 . The mean $\mathrm{IC}_{50}$ value $(\mu \mathrm{g} / \mathrm{ml})$ of ethanolic extract was found to be 9.362 . The concentration of the sample at which the inhibition percentage reaches $50 \%$ is its $\mathrm{IC}_{50}$ value. $\mathrm{IC}_{50}$ values are negatively related to the antioxidant activity as it expresses the amount 
of antioxidant needed to decrease its radical concentration by $50 \%$. The lower $\mathrm{IC}_{50}$ value represents the higher antioxidant activity of the tested sample. Ethanolic extract of $P$. betle L. leaf showed the moderate effect on DPPH radical. The results were given in Table 4 respectively.

\section{ABTS radical scavenging assay}

The mean $\mathrm{IC}_{50}$ value $(\mu \mathrm{g} / \mathrm{ml})$ for ABTS radical of ascorbic acid was found to be 5.354 . The mean $\mathrm{IC}_{50}$ value $(\mu \mathrm{g} / \mathrm{ml})$ of ethanol extract was found to be 6.606 . The concentration of the sample at which the inhibition percentage reaches $50 \%$ is its $\mathrm{IC}_{50}$ value. $\mathrm{IC}_{50}$ values are negatively related to the antioxidant activity as it expresses the amount of antioxidant needed to decrease its radical concentration by $50 \%$. The lower $\mathrm{IC}_{50}$ value represents the higher antioxidant activity of the tested sample. Ethanolic extract of $P$. betle $\mathrm{L}$. leaf showed the moderate effect on ABTS radical. The results were given in Table 4, respectively.

\section{DISCUSSION}

P. betle L. is an important species of the Piperaceae family, green and constant creeper, with heart-shaped leaves that are wonderful reservoirs of phenolic compounds with antiproliferative, antimutagenic, antibacterial, and antioxidant properties. Hence, the present study, phytochemical activity results show alkaloids, flavonoids, tannin, phenol, steroid, saponin, and quinone. The previous phytochemical studies have shown that $P$. betle L. contains a wide variety of various biologically active compounds whose concentration depends on the plant species. Many researches have focused on P. betle $\mathrm{L}$. and have reported that it contains important chemical constituents. These components are valued as a stimulant for its medicinal properties such as antiplatelet, anti-inflammatory effects as well as immunomodulatory, gastroprotective, and antidiabetic activity [24].

In the present study was to evaluate the antidiabetic and antioxidant effects of ethanolic extract of $P$. betle L. The ethanolic extract showed good antidiabetic activity compared to the positive control acarbose. Many research studies to date have given a lot of potential information about $P$. betle $\mathrm{L}$. and its activity as such as antidiabetic and antioxidant properties. These findings are comparable to those observed in a previous study that evaluated the possibility of $P$. betle L. as a nutraceutical for diabetes mellitus patients were treated with either $P$. betle L. or triphal (an herbal antidiabetic drug). Earlier results established the ability of $P$. betle L. capsules made from spray-dried powder of betel hot water extract as a potential treatment for Type 2

Table 1: Phytochemical analyses of leaf extract of $P$. betle

\begin{tabular}{lll}
\hline Phytochemical & Test & Ethanol extract \\
\hline Alkaloids & Wagner & + \\
Flavonoids & Ferric chloride & + \\
Tannin and Phenol & Ellagic acid & + \\
Glycosides & Keller-Kiliani & + \\
Sterol & Salkowski & + \\
Saponin & Foam & + \\
Quinone & - & + \\
\hline
\end{tabular}

${ }^{*}(+)$ indicates presence of phytochemicals. P. betle: Piper betle

Table 2: The $\alpha$-amylase inhibitory effect of ethanol extract of P. betle

\begin{tabular}{llllll}
\hline Concentration $(\mu \mathrm{g})$ & Acarbose & & & \multicolumn{2}{l}{ Ethanol extract } \\
\cline { 2 - 3 } \cline { 5 - 6 } & \% inhibition & $\left(\mathbf{I C}_{\mathbf{5 0}}\right)$ & \% inhibition & $\left(\mathbf{I C}_{\mathbf{5 0}}\right)$ \\
\hline 3.125 & $33.85 \pm 0.05$ & & & $54.09 \pm 0.08$ & \\
6.25 & $42.06 \pm 0.16$ & & $58.41 \pm 0.07$ & \\
12.5 & $61.11 \pm 0.12$ & 7.672 & & $71.52 \pm 0.07$ & 3.038 \\
25 & $73.99 \pm 0.07$ & & & $80.18 \pm 0.57$ & \\
50 & $82.27 \pm 0.09$ & & & $87.13 \pm 0.17$ & \\
100 & $93.74 \pm 0.09$ & & $96.59 \pm 0.10$ & \\
\hline
\end{tabular}

*Data represented as mean \pm SD $(n=3)$; statistical significant level at $(\mathrm{p}<0.05)$.

SD: Standard deviation, P. betle: Piper betle diabetes patients [25]. In vitro analysis of the antidiabetic activity of Caesalpinia digyna, ethanolic extract showed significant inhibition of $\alpha$-amylase at $1 \mathrm{mg}(61.31 \%)[26]$ whereas ethanolic extract of P. betle $\mathrm{L}$. has shown best inhibition activity against at $1 \mathrm{mg}(87.13 \%)$.

In the present investigations on P. betle L. ethanolic extract induced from blood, liver, tissues, and epaxial musculature (tested in fasted catfish, Clarias gariepinus). After $3 \mathrm{~h}$, the glucose-induced fish hyperglycemic level was observed. And the $P$. betle $\mathrm{L}$. ethanolic extract was treated with glucose induced fish; results were compared with a standard drug. The injection of glucose induced fish level range was observed at after $24 \mathrm{~h}$. The increased glycogenesis may result from enhanced glucose induced from the blood, liver, tissues, and epaxial musculature by insulin inducing the activity of enzymes involved in glycogen synthesis and concluded that $P$. betle $\mathrm{L}$. has better antidiabetic activity and comparable [27]. Inhibition of $\alpha$-amylase by methanol extract Psidium guajava has shown $96.3 \%$ of inhibition of $1 \mathrm{ml}$ of the extract [28] which was significant inhibition whereas $P$. betle $\mathrm{L}$. has shown inhibition of lower concentration. Hyperglycemic effect of water glucose indication was observed in zebrafish model along with induction of alloxan solution after $30 \mathrm{~min}$ [29], whereas in catfish, the effect was seen after injection of glucose in epaxial musculature. The blood glucose level in diabetic Swiss albino mice was reduced gradually after $24 \mathrm{~h}$ of oral feeding of P. betle L. extract, the effect was significant compared with control [30], whereas in catfish also, the glucose level significantly reduces after $24 \mathrm{~h}$ of oral ingestion.

Similarly, Kaleem et al. [31] have suggested that the P. betle L. also can be used effectively in the treatment of diabetes. Oral administration of the water extract from the whole plant of Piper sarmentosum Roxb. (Chaplu) at doses of 0.125 and $0.25 \mathrm{~g} / \mathrm{kg}$ significantly lowered the plasma glucose levels in healthy rats. In contrast, the repeated oral administration of the water extract at a dose of $0.125 \mathrm{~g} / \mathrm{kg}$ for 7 days produced a hypoglycemic effect in the diabetic rats. In the comparable previous study, results have the aqueous extract of Piper nigrum seeds that were administered orally to alloxan-induced diabetic rats once a day for 4 weeks. These treatments lead to a significant lowering of blood sugar level and reduction in serum lipids.

Hence, the focus on the present investigation, the antioxidant activity of $P$. betle L. analyzed by DPPH radical scavenging assay and ABTS scavenging assay. The ethanolic extract of $P$. betle L. showed the maximum activity of DPPH and minimum activity of ABTS assay. In previous study, phenolic compounds which were obtained in highest

Table 3: Effect of blood glucose $(\mathrm{mg} / \mathrm{dl})$ level in P. betle extract-treated catfish (C. gariepinus)

\begin{tabular}{lllll}
\hline Sample & Group 1* & Group 2* & Group 3* & Group 4* \\
\hline Blood & $1.3 \pm 0.15$ & $3.7 \pm 0.2$ & $1.0 \pm 0.40$ & $1.9 \pm 0.35$ \\
Liver & $0.5 \pm 0.1$ & $0.5 \pm 0.20$ & $0.2 \pm 0.1$ & $0.5 \pm 0.25$ \\
Tissue & $0.02 \pm 0.02$ & $0.2 \pm 0.20$ & $0.2 \pm 0.26$ & $0.2 \pm 0.25$ \\
Epaxial & $0.01 \pm 0.00$ & $3.6 \pm 0.2$ & $0.2 \pm 0.1$ & $0.8 \pm 0.2$
\end{tabular}

musculature

*Data represented as mean $\pm \mathrm{SD}(\mathrm{n}=3)$; statistical significant level at $(\mathrm{p}<0.05)$

*Group 1 - Control, *Group 2 - Fish injected with glucose (diabetic control).

${ }^{*}$ Group 3 - Fish injected with glucose and metformin hydrochloride,

*Group 4 - Fish injected with glucose and $P$. betle extract. SD: Standard deviation, P. betle: Piper betle

Table 4: $\mathrm{IC}_{50}$ values of $P$. betle for various antioxidant assays

\begin{tabular}{lll}
\hline Antioxidant assay & \multicolumn{1}{l}{$\mathrm{IC}_{\mathbf{5 0}}$ concentration $(\boldsymbol{\mu g} / \mathbf{m l})$} \\
\cline { 2 - 3 } & Ascorbic acid & Ethanol extract \\
\hline DPPH & 3.128 & 9.362 \\
ABTS & 5.354 & 6.606 \\
\hline
\end{tabular}

*Data represented as mean \pm SD $(\mathrm{n}=3)$; statistical significant level at $(\mathrm{p}<0.05)$

SD: Standard deviation, P. betle: Piper betle 


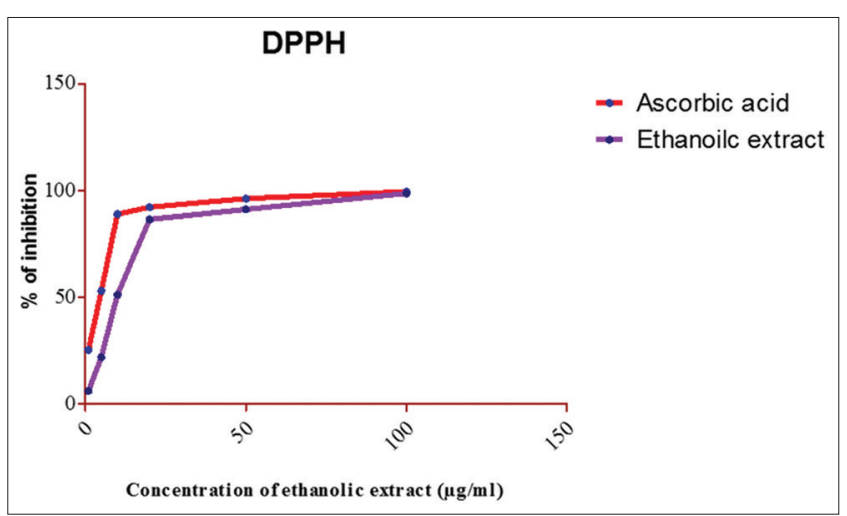

Fig. 1: 2,2-diphenyl-l-picrylhydrazyl scavenging activity of ethanolic extract of $P$. betle

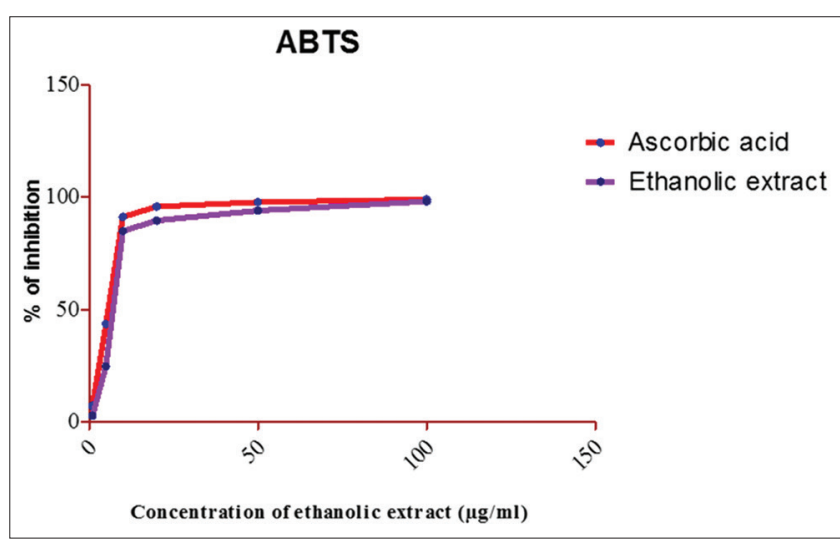

Fig. 2: Azino-bis(3-ethylbenzothiazoline-6-sulfonic acid) scavenging activity of ethanolic extract of $P$. betle

amount in the methanol extract of P. betle L. analyzed by DPPH radical scavenging assay, ABTS scavenging assay, FRAP, PCL assay [32] whereas the phenolic compound was obtained in ethanolic extract of $P$. betle L. that showed significant antioxidant activity. In vitro antioxidant assay using hydroxyl radical scavenging assay and ferric reducing antioxidant potential assay has shown the significant antioxidant activity of aqueous extract of $P$. betle L. [33]. In the previous result, $\alpha$-amylase and $\alpha$-glucosidase inhibition assays were observed that extract of petroleum ether had the highest inhibitory action on the activity values: $91 \% \pm 0.06$ and $42 \% \pm 0.01$ when compared to the standard acarbose [34].

Similarly, the antioxidant activity of chloroform and ethyl acetate extracts of $P$. betle L. leaves with $\mathrm{IC}_{50}$ values $9.187 \mu \mathrm{g} / \mathrm{ml}$ and $4.56 \mu \mathrm{g} /$ $\mathrm{ml}$, respectively [35], the three extracts of $P$. betle L. demonstrated considerable ferric reducing capabilities, with the ethyl acetate extracts having the strong activity [36]. And the aqueous extracts of three local varieties of $P$. betle $\mathrm{L}$. had significant antioxidant activity. The levels of antioxidant enzymes, catalase, and glutathione peroxidase decreased in glucose-induced diabetic catfish; however, these levels returned to normal in insulin and $P$. betle L. treated catfish. In the present results recommend that oxidative stress plays a major role in diabetes, and treatment with $P$. nigrum is useful in controlling not only the glucose and lipid levels but these components may also be helpful in support the antioxidant potential [31]. In the previous study, the existence of the difference in total phenolic content, flavonoid content, and antioxidant properties among different cultivars of P. betle L. [37]. Finally, the recorded antidiabetic and antioxidant properties of ethanolic extract $P$. betle $\mathrm{L}$. could be due to the phenolic compound. Future, the P. betle for specific use in the pharmaceutical industry was suggested.

\section{CONCLUSION}

The present study revealed that ethanol extract was more effective in antidiabetic and antioxidant assays. Therefore, the findings of the present study could form a basis for the development of new pharmaceutical formulations for the treatment of antidiabetic activity.

\section{ACKNOWLEDGMENTS}

The authors are grateful to the authorities of Prince Shri Venkateshwara Arts and Science College for providing the necessary facilities to carry out this research work. Grateful thanks are also due to Greensmed Labs, Chennai-97, for his kind help in antioxidant assays.

\section{AUTHORS' CONTRIBUTION}

Parthasarathi Perumal designed, performed all works and wrote the article. Kavitha Saravanabhavan supervised the work and performed the careful revision of this article, and all the authors have read and approved the final copy of this article.

\section{CONFLICTS OF INTEREST}

The authors have no conflict of interest to declare.

\section{REFERENCES}

1. Hashempur MH, Heydari M, Mosavat SH, Heydari ST, Shams M. Complementary and alternative medicine use in Iranian patients with diabetes mellitus. J Integr Med 2015;3(5):19-325.

2. Zhang Q, Xiao X, Li M, Li W, Yu M, Zhang H. Chromium-containing traditional Chinese medicine, Tianmai Xiaoke Tablet improves blood glucose through activating insulin-signalling pathway and inhibiting PTP1B and PCK2 in diabetic rats. J Integrat Med 2014;12(3):162-170.

3. American Diabetes Association. Diagnosis and classification of diabetes mellitus. Diabetes Care 2010;33:62-9.

4. Kaul K, Tarr JM, Ahmad SI, Kohner EM, Chibber R. Introduction to diabetes mellitus. Adv Exp Med Biol 2012;978:4614-5441.

5. Moller DE. New drug targets for Type 2 diabetes and the metabolic syndrome. Nature 2001;414:821-827.

6. Rees DA, Alcolado JC. Animal models of diabetes mellitus. Diabetic 1. Medicine 2004;22:359-370.

7. Srinivasan K, Ramarao P. Animal models in Type 2 diabetes research: An overview. Indian J Med Res 2007;125:451-472.

8. Etuk EU. Animals models for studying diabetes mellitus. Agric Biol J N Am 2010;1(2):130-134.

9. Viana GS, Medeiros AC, Lacerda AM, Leal LK, Vale TG, Matos FJ, et al. Hypoglycemic and anti-lipemic effects of the aqueous extract from Cissus sicyoides. BMC Pharmacol 2004;4(9):1471-2210.

10. Bhattacharya S, Banerjee D, Bauri AK, Chattopadhyay S, Bandyopadhyay SK. Healing property of the piper betel phenol, allylpyrocatechol against indomethacin-induced stomach ulceration and mechanism of action. World J Gastroenterol 2007;13(27):3705- 3713.

11. Satish AB, Deepa RV, Rohan VG, Nikhil CT, Yatin YR, Vinodkumar SD. Phytochemistry, pharmacological profile and therapeutic uses of Piper betle Linn.-An overview. J Pharm Phytochem 2013;1(2):10-19.

12. Arambewela LS, Arawwawala LD, Ratnasooriya WD. Antinociceptive activities of aqueous and ethanol extracts of Piper betle leaves in rats. Pharm Biol 2005;43(9):766-772.

13. Jayalakshmia B, Raveesha KA, Muralic M, Amruthesh KN. Phytochemical, antibacterial and antioxidant studies on leaf extracts of Piper betle L. Int J Pharm Pharm Sci 2015;7(10):23-29.

14. Abhinayani G, Naga Kishore R, Benazir F, Agarwal P. Anti-diabetic activity of Epipremnum aureum.L in normal and alloxan-induced. Asian J Pharm Clin Res 2016;9(4):89-92.

15. Long, David G. Royal Botanic Garden Edinburgh No. 1753. 1:28. Available from: http://www.data.rbge.org.uk/herb/E00313763.

16. Bhatt SD, Bora PS. Effects of some drugs on islet function in catfish. Indian J Physiol Pharmacol 1984;28(3):201-205.

17. William EN. Catalog of Fishes ed. California, USA: Research and Information; 1998. p. 1-3.

18. Teugels GG. A systematic revision of the African species of the genus Clarias (Pisces; Clariidae). Ann Mus R Afr Centr Sci Zool 1986;247:199-248

19. Harborne JB. Phytochemical Methods. $1^{\text {st }}$ ed. London: Chapman and 
Hall Ltd.; 1973. p. 49-88.

20. Fei Q, Gao Y, Zhang X, Sun Y, Hu B, Zhou L. Effects of oolong tea polyphenols, EGCG, and EGCG3 me on pancreatic $\alpha$-amylase activity in vitro. J Agric Food Chem 2014;62:9507-9514.

21. Praful BG. Textbook of Medical Laboratory Technology. India: Bhalani; 1994. p.108-111.

22. Liyana-Pathirana CM, Shahidi F. Antioxidant activity of commercial soft and hard wheat (Triticum aestivum L.) as affected by gastric $\mathrm{pH}$ conditions. J Agric Food Chem 2005;53:2433-2440.

23. Re R, Pellegrini N, Proteggente A, Pannala A, Yang M, Rice-Evans C, et al. Antioxidant activity applying an improved ABTS radical cation decolorization assay. Free Radic Biol Med 1999;26(9):1231-1237.

24. Rekha VP, Manideep K, Srinivasa BR, Bharath Y, Krishna KP. A review on Piper betle L.: Nature's promising medicinal reservoir. Am J Ethnomed 2014;1(5):276-289.

25. Bhattacharya S, Subramanian M, Bauri A, Kamat JP. Radioprotecting property of the ethonolic extract of the Piper betel leaf. J Radiat Res 2005; $46: 165-171$

26. Narkhede MB, Ajimire PV, Wagh AE, Mohan M, Shivashanmugam AT. In vitro antidiabetic activity of Caesalpina digyna (R.) methanol root extract. Asian J Plant Sci Res 2011;1(2):101-106.

27. Arambewela LS, Arawwawala LD, Ratnasooriya WD. Antidiabetic activities of aqueous and ethanolic extracts of Piper betle leaves in rats. J Ethnopharm 2005;102:239-245.

28. Manikandan R, Anand AV, Muthumani GD. Phytochemical and in vitro anti-diabetic activity of methanolic extract of Psidium guajava leaves. Int J Curr Microbiol App Sci 2013;2(2):15-19.
29. Eunji S, Bin NH, Tong HK. An optimal establishment of an acute hyperglycemia zebrafish model. Afr J Pharm Pharm 2012;6(42):29222928.

30. Rupali S, Chhaya SS, Karmarkar SM, BhagwatAM. Antihyperglycaemic effects of herbal extracts on alloxan induced hyperglycaemic mice. Int J Pharm Pharm Sci 2011;3:307-10.

31. Kaleem M, Sheema H, Sarmad H, Bano B. Protective effects of Piper nigrum and Vinca rosea in alloxan induced diabetic rats. Indian $\mathrm{J}$ Physiol Pharmacol 2005;3(4):307-310.

32. Jaiswal SG, Patel M, Saxena DK, Naik SN. Antioxidant properties of Piper betel (L) leaf extract from six different geographical domain in India. J Bioresour Eng Technol 2014;2:12-20.

33. Gowhar AS, Tajamul IS, Sanjay T. Evaluation of bioactive constituents and in-vitro antioxidant activity of different extracts of Piper betle L. Leaves. World J Pharm Res 2015;4(8):2259-2269.

34. Palak T, Nathiya R, Gayathri M. Antidiabetic activity of endophytic fungi isolated from Ficus religiosa. Asian J Pharm Clin Res 2017;10 (4):59-61.

35. Monirul KI, Amran MH, Gopal CK, Israt JB, Rajib A. Free radical scavenging activity of chloroform and ethyl acetate extracts of leaves of Piper betle Linn. Libyan Agric Res Center J Int 2010;1(6):384-387.

36. Nur MM, Kanthimathi MS, Azlina AA. Comparisons between the antioxidant activities of the extracts of Anacardium occidentale and Piper betle. Malay J Biochem Mol Biol 2008;16:16-21.

37. Bhuvaneswari S, Sripriya N, Deepa S, Udaya Prakash NK. Studies on antioxidant activities of six cultivars of Piper betle linn. Int J Pharm Pharm Sci 2014;6 (11):270-273. 